ФОРМУВАННЯ ПРОФЕСІЙНОЇ КОМПЕТЕНТНОСТІ

МАЙБУТНІХ ОФІЦЕРІВ У ПРОЦЕСІ ВИВЧЕННЯ ЗАГАЛЬНОВІЙСЬКОВИХ ТАКТИКО-СПЕЦІАЛЬНИХ ДИСЦИПЛІН

\title{
BUILDING FUTURE OFFICERS PROFESSIONAL COMPETENCE IN THE PROCESS OF STUDYING COMBINED ARMS TACTICAL SPECIAL DISCIPLINES
}

УДК 355.237.3:37.012(043.3)

DOI https://doi.org/10.32843/2663-

$6085 / 2019.21 .2-28$

\section{Король Я.І.,}

канд. пед. наук,

заступник начальника кафедри тактики та загальновійськових дисциплін

Військової академії (м. Одеса)

\section{Суслов В.В.}

старший викладач кафедри тактики

та загальновійськових дисциплін

Військової академії (м. Одеса)
Статтю присвячено актуальній проблемі формування профресійної компетентності майбутніх ооріцерів у процесі вивчення загальновійськових тактико-спеціальних дисциплін. На заняттях з тактико-спеціальної підготовки курсанти вищих військових навчальних закладів набувають навички з підготовки та проведення заходів інженерного забезпечення, радіаційного, хімічного, біологічного захисту, практичної роботи на різних зразках озброєння та військової техніки. Підвищення ролі тактико-спеціальної підготовки зумовлено тим, що в процесі проведення різних видів занять із тактико-спеціальних дисциплін (практичні заняття, групові вправи, тактико-спеціальні заняття, командно-штабні навчання) моделюються різні ситуації, в тому числі максимально наближені до реальної бойової обстановки.

у статmі розглянуто теоретичні засади підготовки майбутніх офріцерів до професійної діяльності у прочесі вивчення загальновійськових тактико-спеціальних дисциплін, зміст профресійної підготовки у сучасних умовах, виділено принципи, які впливають на формування професійної компетентності майбутніх офріцерів: єдність навчання і виховання, інтегративність, цілеспрямованість, мотивацію, практичність, реальність. Спираючись на наукові доробки закордонних і українських учених та результати експертного опитування, було визначено основні напрями вдосконалення підготовки майбутніх офріцерів до професійної діяльності в прочесі вивчення загальновійськових тактико-спеціальних дисциплін. До педагогічних умов підвищення ефективності прочесу формування профресійної компетентності майбутніх офбіцерів віднесено: створення діалогічного простору в організачії учбового процесу; формування психологіч ної готовності викладачів до використання інтерактивних форм навчання $з$ тактикоспеціальних дисциплін; побудова організаціі інтерактивних методів і форм на основі сучасних технічних засобів; моделювання на заняттях із тактико-спеціальних дисциплін різних ситуацій практичної спрямованості. Ключові слова: майбутні офріцери, просресійна діяльність, формування профресійної компетентності, принципи, тактико-спеціальні дисципліни.

The article deals with the urgent problem of the future officers' professional competence formation in the process of studying combined arms tactical special disciplines. During tactical special training, cadets of higher military educational institutions acquire skills of preparation and conduct of engineering support, chemical, biological and radiological protection, practical exploitation of various types of weapons and military equipment. The increasing importance of tactical special training is due to the fact, that different situations, including those which are as close as possible to the real combat environment, are simulated during various types of tactical special training (practical training, training exercises, tactical special trade specific training, command and staff training).

The theoretical fundamentals of the training for professional activities of future officers in the process of studying combined arms tactical special disciplines, the content of professional training in modern conditions are discussed in the article. The article identifies principles, which affect the building of future officers' professional competence: training and education unity, integrativeness, purposefulness, motivation, practicability, actuality.

From the perspective of the scientific achievements of foreign and Ukrainian scientists and following on from results of the expert survey, the main directions of improvement of the training of future officers for their future professional activity in the process of studying combined arms tactical special disciplines were determined.

The pedagogical conditions of increasing the efficiency of the building of future officers' professional competence include: creating a dialog space in the educational process organization developing instructors' psychological readiness to use interactive forms of tactical special disciplines training; organization of interactive methods and forms utilizing modern technical means; simulation of different practical oriented situations during tactical special disciplines training. Key words: future officers, professional activity, building professional competence, principles, tactical special disciplines.
Постановка проблеми у загальному вигляді. Матеріали сучасних закордонних та вітчизняних публікацій показують, що значна увага приділяється аналізу загроз та сучасного характеру ведення бойових дій, а досвід локальних війн та збройних конфрліктів останніх десятиліть свідчить про те, що ефективно виконувати бойові завдання спроможні лише професійно підготовлені військовослужбовці [1-4].

Враховуючи це, однією 3 важливіших задач військової освіти на сучасному етапі $€$ якісна про- фресійна підготовка офріцерів командного та інженерно-технічного складу, які готові до компетентного виконання своїх службових обов'язків як у звичайних умовах повсякденної діяльності, так і в екстремальних ситуаціях під впливом різноманітних стресогенних чинників.

Для цього вбачається доцільним впроваджувати ефрективні освітні програми, здійснювати своєчасне вивчення досвіду бойових дій, аналізувати зміни, які відбуваються в характері та способах ведення збройної боротьби, і на основі цього 
вносити корективи в навчальні програми вивчення тактичних та тактико-спеціальних дисциплін. При цьому головним критерієм оцінки якості навчання повинна стати не лише індивідуальна спроможність до виконання функціональних обов'язків, а і здатність до підтримання безперервності управління підпорядкованими підрозділами в різних умовах бойової обстановки.

Саме тому серед великої кількості навчальних дисциплін, які вивчаються у вищих військових навчальних закладах, тактична та тактикоспеціальна підготовка займають провідні місця, оскільки вони визначають спроможність випускника в подальшому виконувати задачі у відповідності до посади, на яку він буде призначений.

Аналіз останніх досліджень і публікацій. Підвищення ролі загальновійськової тактико-спеціальної підготовки пов'язане з тим, що у процесі проведення різних видів занять (практичних занять, групових вправ, воєнно-спеціальних ігор, командно-штабних навчань тощо) моделюються різні ситуації та напрями професійної діяльності майбутніх ооріцерів. Тактико-спеціальна підготовка $€$ динамічним складником спеціальних знань, якими життєво необхідно оволодіти майбутньому офріцеру. На заняттях 3 тактико-спеціальної підготовки курсанти набувають навички 3 підготовки та проведення заходів інженерного забезпечення, радіаційного, хімічного, біологічного захисту, практичної роботи на різних зразках озброєння, техніки, засобах та ін.; розробляють та офрормлюють бойові та службові документи; вирішують тактичні та спеціальні завдання в обстановці, що наближена до реальної бойової. Тобто основними завданнями тактико-спеціальної підготовки є виховання високих моральних та вольових якостей, фрормування навичок системного прийняття рішень на виконання поставлених завдань у будь-яких умовах, у тому числі екстремальних, пов'язаних з діями підрозділів на заражених ділянках місцевості, в районах пожеж, затоплень тощо.

Підготовка майбутніх офріцерів до профресійної діяльності була предметом розвідок І. Руснака, О. Діденко, Ю. Сердюка, В. Стасюка. Окремі аспекти організації фрормування професійної компетентності та концептуальні основи профресійної підготовки майбутніх офріцерів досліджували В. Ягупов, Ю. Ленев, В. Байденко, О. Маслій, Л. Джигун, О. Бігич, І. Новак, Ю. Лісніченко та ін.

Виділення не вирішених раніше частин загальної проблеми. За результатами досліджень, публікацій та відгуків на випускників вищих військових навчальних закладів відмічається загальна риса щодо їх недостатньо високого рівня вмінь та навичок оперативного реагування на динамічні зміни в обстановці, тактику дій противника. Результати проведення заходів щодо підвищення ефрективності профресійної під- готовки курсантів вищих військових навчальних закладів показують, що накопичений досвід навчання і виховання у вітчизняній військовій школі не завжди використовується повною мірою, іноді бездумно копіюються елементи, що притаманні військовим школам інших країн, а програми навчання і навчально-методичні матеріали не повністю відповідають сучасним вимогам щодо підготовки військових фрахівців, недостатньо широко впроваджуються в освітній процес результати актуальних наукових досліджень. На зниження якості професійної підготовки майбутніх офріцерів істотно впливає те, що на зміну висококваліфрікованим досвідченим викладачам приходять молоді, тобто такі, що не мають достатнього досвіду науково-педагогічної діяльності та рівня методичної і професійної підготовленості [5].

Мета статті полягає в розгляді основних аспектів фрормування професійної компетентності майбутніх офріцерів як складника готовності їх до професійної діяльності, а також визначення шляхів та виявлення особливостей її формування у процесі вивчення загальновійськових тактико-спеціальних дисциплін на засадах компетентнісного підходу.

Виклад основного матеріалу дослідження. Профресійна діяльність буде ефективною лише за умови ґрунтовної і всебічної фрахової підготовки, що передбачає планомірні, організовані заходи, спрямовані на засвоєння військово-професійних знань, оволодіння вміннями і навичками, фрормування професійно важливих якостей особистості, що відповідають вимогам профресії.

Жорсткі умови сучасності, в тому числі на фроні поширення концепції гібридної війни, характерними рисами якої є порушення країною-агресором діючих міжнародних норм, нехтування укладеними угодами та досягнутими домовленостями, широке використання країною-агресором незаконних збройних формувань та диверсійних груп, вимагають відповідної зміни змісту і методів навчання, максимального наближення навчання до реалій сучасності.

Загальновійськова тактико-спеціальна підготовленість - це обґрунтовано необхідний і достатній рівень профресійно-значимих якостей випускника вищого військового навчального закладу, гарантуючий успішне виконання поставлених бойових завдань незалежно від умов та складності обстановки. Її основними складниками є тактико-спеціальні знання, вміння і навички, а також особисті якості майбутнього офріцера.

Тактико-спеціальна підготовка $€$ провідним предметом навчання майбутніх офріцерів. Вона визначає необхідний обсяг знань, рівень професійної навченості особового складу і принципові напрями процесу навчання. Це зумовлює місце і роль тактико-спеціальної підготовки в подальшому успішному виконанні бойових завдань 
випускниками ВВН3. Тактико-спеціальна підготовка $€$ основою польового вишколу військ.

Загальновійськова тактико-спеціальна підготовка має на меті набуття курсантами вмінь раціонально діяти в особливих умовах та фрормування високої психологічної стійкості і постійної готовності злагоджено виконувати завдання за призначенням у складній бойовій обстановці спільно з підрозділами інших родів військ та військових форомувань.

В її основі лежать: вивчення основ загальновійськового бою; тактика дії своїх і взаємодіючих родів військ і спеціальних військ; організація і бойові можливості своїх військ і противника; навчання особового складу ефективному застосуванню озброєння і техніки; вироблення у військовослужбовців високих морально-бойових якостей; вдосконалення умінь і навичок в організації і здійсненні бойового забезпечення; управління підпорядкованими підрозділами і забезпечення взаємодії під час підготовки і ведення бойових дій.

3 урахуванням фрункцій, які при цьому виконуються, до занять з тактико-спеціальної підготовки висуваються такі загальні вимоги: науковість, доступність, комплексність, зв'язок з іншими військово-професійними дисциплінами і практикою. Структура тактико-спеціальної підготовки курсантів включає три компоненти: підготовленість, готовність і надійність.

Методика навчання 3 тактико-спеціальних дисциплін передбачає комплексне і раціональне застосування в освітньому процесі методів, прийомів і засобів навчання.

Натепер під час проведення занять із загальновійськових тактико-спеціальних дисциплін застосовуються в різних комбінаціях такі методи навчання: усне викладання навчального матеріалу (лекція, розповідь, інструктаж та інше); обговорення матеріалу (семінар, співбесіда, дискусія, бесіда та інше); показ (демонстрація засобів наочності, особистий показ, показ дій підрозділів та ін.); вправи (аналіз конкретних ситуацій, тренування та ін.); практична робота; самостійна робота (з друкованими джерелами, на технічних засобах, за допомогою інтерактивних засобів). Активно впроваджуються технології імітаційного моделювання.

Формування профресійної компетентності майбутніх офріцерів під час вивчення тактико-спеціальних дисциплін безпосередньо залежить від умов навчання та спрямованості цілей і змісту військової освіти загалом.

Профресійна компетентність майбутніх офріцерів як складова частина їх готовності до майбутньої профресійної діяльності насамперед виражається в їх суб'єктивній та об'єктивній готовності до прийняття рішень, які забезпечуватимуть успішне виконання завдань, особливо в умовах бойової обстановки. Вона може розглядатись як інтегрована властивість особистості, показник якості іï̈ підготовки, що характеризується ступенем здатності до застосування сорормованих знань, умінь, навичок, професійних, світоглядних і громадських якостей.

До особливостей професійної компетенції військових фрахівців за метою, завданнями та результатами службової діяльності відносять інтегративний характер результатів виконання службових завдань, що поєднують у собі бойову готовність підрозділів, морально-психологічний стан військового колективу та якісні зміни в конкретній особі військовослужбовця.

Формування профресійної компетентності майбутніх офріцерів здійснюється в контексті всебічної підготовки та становлення військових кадрів. Воно зумовлено безперервним процесом навчання та розвитку курсантів у межах системного підходу до організації освітнього процесу у вищому військовому навчальному закладі.

На фрормування професійної компетентності майбутніх офріцерів впливають перераховані нижче принципи:

- єдність навчання і виховання - полягає в забезпеченні в процесі підготовки формування як власно професійних, так і особистісних індивідуально-психологічних та професійно важливих якостей і здібностей майбутніх офріцерів;

- інтегративність - полягає в забезпеченні взаємозв'язку між загальнонауковими, загальновійськовими та спеціальними дисциплінами і в міждисциплінарній комплексності;

- мотивація - полягає у забезпеченні достатнього рівня мотивації майбутніх офріцерів щодо підтримки зацікавленості у високих результатах підготовки та сорормованості фрахової компетентності;

- цілеспрямованість - полягає у забезпеченні цілеспрямованості кожного етапу підготовки і фрормування компетентності майбутніх офріцерів;

- практичність - полягає у забезпеченні практичної спрямованості підготовки і фрормування компетентності майбутніх офріцерів, насамперед щодо високих рівнів сорормованості їхніх профресійних умінь і навичок;

- реальність - полягає в організації підготовки і орормування компетентності майбутніх офріцерів у реальних умовах, що будуть максимально наближені до бойових, а також до умов їхньої майбутньої служби у військах;

- наступність - полягає у створенні в процесі підготовки умов для врахування попереднього професійно важливого досвіду майбутніх офріцерів.

Профресійна компетентність майбутніх офріцерів у процесі вивчення тактико-спеціальних дисциплін представляєтьсяякєдністьтеоретичноїіпрактичної 
їх готовності до профресійної діяльності, професійні характеристики яких подано чотирма групами:

1. Сукупність знань і вмінь, необхідних для активного опанування нових знань; орієнтація на освоєння умінь та способів діяльності; уміння ставити професійно-військові завдання виділення комплексу освітньо-фрахових, виховних і розвиваючих завдань, їх конкретизація; комплекс особистісних профресійно значущих якостей; обсяг навичок виконання профресійних завдань та їх конкретизації, а також особистісні якості для досягнення необхідного результату під час виконання військових завдань.

2. Комплексний, обґрунтований відбір змісту освітньо-військового процесу; оптимальний вибір методів освітньо-професійних і творчих завдань та способів їх виконання; комплексна фрорма пізнання і здійснення військово-професійної діяльності; уміння програмувати способи військової взаємодії та побудови логічної військово-педагогічної системи виконання професійних завдань.

3. Виконання професійно-військових дій, передбачення та встановлення взаємозв'язку між усіма компонентами поставлених завдань та приведення їх у дію з урахуванням усіх фракторів компетенції майбутніх фрахівців.

4. Аналіз та самоаналіз результатів вирішення поставлених завдань як підсумку військової діяльності; проведення обліку комплексних профресійних завдань, які є фрактором успішності їхньої військово-професійної діяльності.

У процесі вивчення тактико-спеціальних дисциплін професійна компетентність майбутніх офріцерів реалізується через:

1) комплексну систему підготовки майбутніх офріцерів до професійної діяльності, яка забезпечується системою військової освіти з урахуванням цілей і завдань, які впливають на зміст, фрорми, методи, способи організації навчально-виховного процесу, технології та методики навчання з забезпеченням індивідуального підходу на практичну діяльність;

2) фрормування профресійної компетентності майбутніх офріцерів для поглиблення професійних знань, вмінь та навичок, що задіяні у військовоосвітньому процесі, а саме найбільш ефективних методик і технологій навчання за визначеними фраховими програмами, принципами, підходами та практичної підготовки під час тактичних і тактикостройових занять, комплексно-спеціальних і показових занять та навчань;

3) проведення тестових випробувань різного рівня складності на більшості етапів процесу фрормування компетентності майбутніх офріцерів на заняттях.

3 метою підвищення ефективності фрормування профресійної компетентності під час вивчення так- тико-спеціальних дисциплін доцільно обрати компетентнісний підхід.

Реалізація компетентнісного підходу вимагає визначення мети підготовки майбутніх офріцерів з урахуванням їх спеціалізації, тобто якого спеціаліста необхідно отримати в результаті навчання, та яку ступінь сорормованості компетенцій необхідно досягти на окремо визначеному етапі його підготовки з одночасною оптимізацією змісту кожної навчальної дисципліни, в тому числі шляхом здійснення міждисциплінарної координації.

Слід відмітити, що основними умовами оптимізації структури та змісту вивчення тактикоспеціальних дисциплін $є$ наукове розуміння суті і структури процесу фрормування профресійної компетентності у курсантів; ефективне використання потенціалу кожного виду заняття по тактико-спеціальній підготовці; підвищення рівня наукового, кадрового і матеріально-технічного забезпечення; постійне вивчення та доведення військового досвіду для моделювання області професійної діяльності випускників вищих військових навчальних закладів, тобто впровадження практико-орієнтованої моделі реалізації процесу фрормування профресійної компетентності.

До педагогічних умов підвищення ефективності процесу формування професійної компетентності курсантів відносяться: створення діалогічного простору в організації навчального процесу; фрормування психологічної готовності викладачів до використання інтерактивних фрорм навчання з тактико-спеціальних дисциплін; побудова організації інтерактивних методів і форм на основі сучасних технічних засобів; моделювання на заняттях з тактико-спеціальних дисциплін різних ситуацій практичної спрямованості.

Також не слід забувати, що однією з основних фрорм засвоєння навчального матеріалу є самостійна підготовка майбутніх офріцерів, яка спрямована на фрормування професійної компетентності шляхом самостійного вивчення навчального матеріалу, відображеного в нормативних документах, підручниках, інтернет-ресурсах та інших джерелах інфрормації. У разі правильної організації самостійної підготовки есрективним може стати застосування випереджувальних завдань, які спрямовані на часткове самостійне оволодіння матеріалом до його вивчення за програмою, що дасть можливість відійти від стереотипу традиційних лекцій, коли курсант фрактично здійснює лише механічне переписування інорормації.

Реалізувати перехід від класичних лекцій до лекцій-диспутів (лекцій-практики) можливо за рахунок підготовки печатних курсів лекцій. Як наслідок, курсант буде прибувати на лекцію з певним рівнем обізнаності щодо ії матеріалу та зможе не тільки ставити викладачу запитання, а й обговорювати їх. За наявності активної 
позиції курсантів це може зекономити час, що виділяється на вивчення навчальної дисципліни, дозволить покращити якість засвоєння знань та надасть можливість загострювати увагу на сучасних досягненнях науки та практики.

Беручи до уваги, що активність сама по собі виникає нечасто, а є наслідком цілеспрямованої взаємодії та організації педагогічного середовища, реалізація принципу активності можлива в межах інтерактивного навчання в умовах єдиного інформаційного освітнього простору.

До інтерактивних методів викладання загальновійськових тактико-спеціальних дисциплін можна віднести семінари-диспути, вирішення проблемних ситуацій та імітаційні тренінги.

Даний підхід $є$ одним 3 ефективних шляхів забезпечення позитивної мотивації, в тому числі щодо вивчення питань оцінки обстановки, вироблення замислу та прийняття рішення на бій (бойове застосування підрозділів), оскільки при цьому створюються умови, за яких курсанти відчувають свою інтелектуальну самостійність та самодостатність. Мета такого підходу - фрормування стійкого пізнавального інтересу до вивчення тактико-спеціальних дисциплін, підвищення якості засвоєння знань та створення необхідних педагогічних умов для розвитку творчих здібностей майбутніх офріцерів.

Головною умовою реалізації інтерактивного підходу під час вивчення тактико-спеціальних дисциплін $є$ розроблення і використання інтерактивних завдань для їх виконання курсантами (наприклад, розробка завдань постам спостереження, висновків з оцінки обстановки). Такі інтерактивні завдання - це передусім творчі завдання, які потребують від майбутніх офріцерів не лише здатності до простого копіювання інформації, а й утримують у собі певний елемент невизначеності. Вони передбачають таку організацію процесу фрормування профресійної компетенції майбутніх офріцерів, за якої практично неможливо виключення курсантів із процесу пізнання і забезпечується їх суб'єктивна та об'єктивна готовність приймати рішення щодо виконання бойових завдань, що також характеризує і їхню профресійну компетентність.

Висновки. Таким чином, питання фрормування професійної компетентності майбутніх офріцерів у процесі вивчення загальновійськових тактикоспеціальних дисциплін на засадах компетентнісного підходу не втрачає актуальності та потребує додаткового вивчення, оскільки характеризує їхню здатність реалізувати свій потенціал (тактико-спеціальні знання, уміння і навички у сорері бойового застосування і бойової підготовки підрозділів, морально-бойові якості) для ефективного виконання службово-бойових завдань.

Перспективи подальших досліджень вбачаємо в обґрунтуванні теоретичних та методичних засад застосування технології імітаційного моделювання в процесі формування професійної компетентності майбутніх офріцерів.

\section{БІБЛІОГРАФІЧНИЙ СПИСОК:}

1. Левченко О.Є. Хімічна безпека як елемент національної безпеки. Наука і практика. 2014. № 1 (2). С. 38.

2. Слюсаренко А.В. Досвід ведення бойових дій у локальних війнах кінця XX - початку XXI століть, та його використання у підготовці Збройних Сил України. Вісник Національного університету «Львівська політехніка». 2006. С. 172-178.

3. О применении химического оружия боевиками в Сирии. Зарубежное военное обозрение. 2013. № 6. С. 102.

4. Воробьев И.И. Тактика в локальных войнах и вооруженных конфрликтах. Военная мысль. 2006. № 2. С. 26-32.

5. Дудулин В.В. Проблемы профессионального роста современного военного специалиста. мир образования - образование в мире. 2009. № 3 (35). С. 123-127.

6. Маслій О.М. Формування фрахової компетенції майбутніх офріцерів тилу у сорері військово-економічної логістики : дис. ... кандидата пед. наук : 13.00.04 ; Національна академія Державної прикордонної служби України імені Богдана Хмельницького. Хмельницький, 2011. С. 89. 